\title{
Neotropical Monogenoidea. 23. Two New Species of Gyrodactylus (Gyrodactylidae) from a Cichlid and an Erythrinid Fish of Southeastern Brazil
}

\author{
Walter A Boeger, Flávio Popazoglo \\ Departamento de 7,oologia, Universidade Federal do Paraná, Caixa Postal 19073,81531-990 \\ Curitiba, PR, Brasil
}

\begin{abstract}
Two new species of Gyrodactylus Nordmann, 1832 (Platyhelminthes, Monogenoidea) are described from fishes collected from southeastern Brazil. Gyrodactylus gcophagensis n. sp. was collected from the body surface of the "cará", Geophagus brasilicnsis (Quov and (jaimard, 182t) (Cichlidae), from the Rio da Guarda. State of Rio de Janeiro; its major diagnostic features are the morphology of the anchor with a short, truncate superficial root and the shape of the hooks - with a long, delicate shaft. Gyrodactylus trairae $n$. sp. parasitizes the bodv surface of the "traira". Hoplias aff. malabaricus (Bloch. 1794) (Erythrinidae), from the Rio (iuandu, State of Rio de Janeiro and can be easily differentiated from other species of the genus by having a thin, dorsal bridge, connecting the superficial bar with the spathulated shield. These are the first species of Gyrodactylus formally reported from Brazil. Presently, 26 species of Gyrodactylidae are known from freshwater fishes in the Neotropical Region; a list of these species is provided.
\end{abstract}

Key words: Platyhelminthes - Gyrodactylidac - Gyrodactylus geophagensis n. sp. - Gugrodactolus trairae n. sp. - Geophagus brasiliensis - Hoplias aff. malabaricus - Brazil

Until recently. Gyrodactylidae were practically unknown for the Neotropical Region (Table). Kritsky and Fritts (1970) were the first to report and describe species from Ncotropical freshwater fishes collected in Costa Rica. Central America. Only three additional refererences exist from 1970) to the early 80's: Szidat (1973). Kritsky and Thatcher (1977), and Harris (1983). Considering the species described in this paper, there are, presently, 26 gyrodactylids reported for freshwater fishes of the Neotropical Region. The majority of these forms are related to those studied in Peru and Brazil (see Table for references). Only two species are known from Neotropical marine fishes: Gyrodactylus curemae Conroy and Conroy, 1985 was described from Mugil curema Valenciennes, 1836 from Venezucla; and Gyrodactylus sp. reported by Jara (1986) from Mugil cephalus Linné. 1758 from the coast of Peru.

This work received financial support from the Fundação de Amparo e Pesquisa do Estado do Rio de Janeiro (Proc. E-291170-033/90) and Conselho Nacional de I esenvolvimento Científico e Tecnológico (Proc. 406184/90 and $500711190-9)$, Brazil. This is the contibution number 899 from the Departamento de Zoologia, Universidade Federal do Paraná.

Research fellow's CNPq

Received 20 March 1995

Accepted 26 July 1995
Although many of the species of Gyrodactylidae reported from the region are not closely related to each other but to other Neartic or Eurasian species (An el al. 1991). Neotropical fishes are the only known hosts of a unique group of this family of worms. Harris (1983) proposed a new family, Ooegyrodactylidae, to include, at that time. lwo species of oviparous monogenoideans which depicted great morphological similarity to the Gyrodactylidae. Kritsky and Boeger (1991) described four new species of these worms. However. Boeger et al. (1994) rejected monophyly of Ooegyrodactylidae using techniques of Phylogenetic Systematics and transferred all its members to Gyrodactylidae. The Ooegy rodactylidae, according to these authors. is paraphyletic. Thus. the Gyrodactylidae is presently composed of viviparous (the tradicional composition) and of oviparous species (formely members Ooegyrodactylidae). Oviparous Gyrodactylidae have only been found on Neotropical Siluriformes, mainly Loricariidae.

Although specics of Gyrodactylus have already been reported from South America (Jara 1986, An et al. 1991), none have been previously registered from Brazil. However, during a survey of Gyrodactylidae, two new species of Gyrodactylus were collected from fishes of the Southeast Region of the country. These forms are described herein. 


\section{TABLE}

Gyrodactylidae from freshwater fishes of the Neotropical Region

\section{Parasite} Host Species Reference

Accessorius

A. peruensis Jara et al., 1991

\section{Anacanthocotyle}

A. anacanthocotyle Kritsky and Fritts, 1970

A. $\mathrm{sp}$.

\section{Gyrodactylus}

G. neotropicalis Kritsky and Fritts, 1970

G. costaricencis Kritsky and Fritts 1970

(i. bullatarudis Turnbull, 1956

\section{G. lebiasinus An et ai., 1991}

(5. pimelodellus An et al., 1991

G. slendrus An et al., 1991

(i. turnbulli Hartis, 1986

(1. geophagensis Boeger and Popazoglo, nobis

(i. trarrae Boeger and Popazoglo, nobis

G. gemini Ferraz st al., 1994

G. sp.

\section{Hyperopletes}

H. malmbergi Boeger et al., 1994

\section{Nothogyrodactylus ${ }^{2}$}

N. clavatus Kritsky and Boeger, 1991

N. amazonicus Kritsky and Boeger, 1991

$N$. plaesiophallus Kritsky and Boeger, 1991

\section{Ooegyrodactylus}

O. farlowellae Harris, 1983

\section{Paragyrodactyloides}

P. superbus (Szidat, 1973)

\section{Phanerothecium ${ }^{a}$}

P. caballeroi Kritsky and Thatcher, 1977

P. harrisi Kritsky and Boeger, 1991

P. spinicirrum Boeger et al., 1994

\section{Scleroductus}

S. yuncensi Jara and Cone, 1991

S. sp.

\section{Lebrasina bimaculata Cuvier and} Valenciennes, 1846

Astyanax fasciatus (Cuvier, 1819) Bryconamericanus pertuanus Müller and Troschel, 1845

Astyanax fasciatus (Cuvier, 1819)

Poecilia sphenops Valenciennes, 1836

Poecilla sphenops

P. rettculata Peters, 1859

Lebiasina bimaculata

Pimelodella yuncencis Steindachner, 1920

Leblasina bimaculata

Poecilia reticulata

Geophagus brasiliensis

(Quoy and Gaimard, 1824)

Hoplias aff. malabaricus (Bloch, 1794)

Semaprochilodus taenirus

(Valenciennes, 1811)

Trychomycterus punctulatum

Valenciennes, 1840

Rhineloricaria sp.

Ancistrus sp.

Ancistrus sp.

Ancistrus sp.

Farlowella amazonum Günther, 1864

Corydoras paleanus (Jenyns, 1842)

Cephalosilurus zungaro

(Humboldt, 1833)

Hypostomts plecostomus

(Linnaeus, 1758)

Hypostomus punctatus

(Valenciennes, 1840)

Pimelodella yuncensis

Parauchenipterus striatulus

(Steindachner, 1876)

Glanidium melanopterum Ribeiro, 1920

Pimelodella sp.
Kritsky \& Fritts (1970)

Jara (1986)

Kritsky \& Fritts (1970)

Kritsky \& Fritts (1970)

Kritsky $\&$ Fritts $(1970)$

Harris \& Liles (1992)

An et al. (1991)

An et al. (1991)

An et al. (1991)

An et al. (1991)

Harris \& Liles (1992)

Boeger \& Popazoglo (nobis)

Bonger \& Poparoglo (nobis)

Ferraz et al. (1994)

Jara (1986)

Boeger et al. (1994)

Kritsky \& Boeger (1991)

Kritsky \& Boeger (1991)

Kritsky \& Boeger (1991)

Harris (1983)

Szidat (1973)

Kritsky \& Thatcher (1977)

Kritsky \& Boeger (1991)

Boeger et al. (1994)

Jara \& Cone (1989)

Kritsky et al. (1995)

Kritsky et al. (1995)

Kritsky et al. (1995)

Kritsky et al. (1995)

$a$ : genera with oviparous species 


\section{MATERIALS AND METHODS}

Fishes were collected from two localities of the Southeast Region of Brazil, as indicated in the respective descriptions, by different types of nets. Individual or pooled hosis were placed in vials containing a 1:4000 solution of formalin (Putz \& Hoffman 1963). After $1 \mathrm{hr}$, the vials were vigorously shaken and additional formalin was added to increase the concentration to about $5 \%$. Gyrodactylids were prepared according to procedures described in Kritsky et al. (1995). lllustrations were prepared with the aid of a camera lucida. Measurements are given in micrometers; the average is given followed by the range and the number (n) of structures measured, in parenthesis; anchors were measured following method indicated by Kritsty et al. (1995). Type specimens were deposited at the Instituto Oswaldo Cruz (IOC), Rio de Janeiro, Brazil, the University of Nebraska State Museum (HWML), Lincoln, Nebraska, and the U. $S$. National Museum Helminthological Collection (USNM), Beltsville, Maryland, USA, as indicated in the respective descriptions.

\section{DESCRIPTIONS}

Gyrodactylus geophagensis $\mathrm{n}$. sp.

(Figs 1-5)

Host: Geophagus brasiliensis (Quoy and Gaimard, 1824) (Cichlidac)

Site of infestation: body surface

Type locality: Rio da Guarda, Itaguaí, State of Rio de Janciro. Brazil; December 1990

Holotype: IOC 33144a. Paratypes: (4 specimens) IOC 33144b-c: (2 specimens) USNM 84078; (2 specimens) HWML 37095

Description (based on 9 specimens): body elongate. $418(390-455, n=3)$ long; greatest width 103 $(89-117 ; n=4)$ near midlength. Cephalic lobes moderately developed, head organs conspicuous. Pharynx $44(38-53 ; n=6)$ in diameter; pharyngeal process inconspicuous. Testis not observed. Copulatory organ 6-7 $(\mathrm{n}=2)$ in diameter, ovate, armed with 8 spinelets. 1 spine. Germarium ovate. Uterus with up to 2 embryos. Syncytial postgermarian mass of cells. Haptor $79(71-88 ; n=3)$ long, 84-96 $(n=3)$ wide. Anchor $57(55-58 ; n=5)$ long: with slightly curved shaft $40(37-41 . n=5)$ long; point $25(22-28 ; n=5)$ long; truncate, robust superficial root; inconspicuous deep root- base 22 $(19-24 ; n=5)$ long; angle shaft/point $45^{\circ}\left(40^{\circ}-49^{\circ}\right.$; $n=5)$. Superficial bar $20-23(n=2)$ long, $9-19(n=2)$ wide, robust with short antero-lateral projections; shield of superficial bar extending to middle of anchor shaft, tapering posteriorly, 13-14 $(n=2)$ long; deep bar relatively robust, flexible. Hooks with straight shaft, shelf with small proximal elevation, straight thumb, conspicuous heel, slen- der shank; hooklet 7-8 $(n=5)$ long; FH loop not observed.

Remarks: the morphology of the anchor and bar of $G$. geophagensis $\mathrm{n}$. sp. is very similar to those of $G$. masu Ogawa, 1986 and $G$. derjarvini Mikailov, 1975. All three species depict robust anchors with short, truncate superficial root, and superficial bar with shield and anterolateral processes relatively short. Gyrodactylus geophagensis n. sp. can be differentiated from these species by having: (1) hooks with delicate, proportionally ionger shaft and a straight non depressed toe; (2) copulatory organ with spinclets of about equal size - in G. masu and G. derjarvini the spinelets lateral to the cirral spine are larger than the remaining ones. The specific name refers to the generic name of the host of this species.

\section{Gyrodactylus trairae n. sp.} (Figs 6-10)

Host: Hoplias aff. malabaricus (Bloch, 1794) (Erythrinidae)

Site of infestation: body surface

Type locality: Rio Guandu, Nova lguaçu, State of Rio de Janciro, Brazil; April and June 1991

Holotype: IOC 33215a. Paratypes: (8 specimens) IOC 33215b-i; (8 specimens). USNM 84079; (8 specimens) HWML 37096

Description (based on 25 specimens): body elongate, $608(530-667 ; n=8)$ long; greatest width 127 (90-175; $n=8)$ near midlength. Cephalic lobes well developed; head organs conspicuous. Distal pharynx $42(38-47 ; n=6)$ in diameter; proximal pharynx $47(44-49 ; n=6)$ in diameter; pharyngeal processes not observed. Testis post germarian, laterally elongate. Copulatory organ 17-18 $(n=4)$ in diameter, ovate, armed with 1 spine and spinelets arranged in two rows; external row with 4 large spinelets; internal row with 4-5 small intermediate spinelets; base of large spinclets large, truncate. Germarium ovate. Uterus with up to 4 generations of embryos. Vitelline follicles not observed. Numerous unicellular glands in peduncle with ducts directed posteriorly. Haptor 108 (97$123 ; n=12)$ long, $78(71-93 ; n=12)$ wide. Anchor $107(102-114 ; n=11)$ long, with straight shaft, 46 $(41-51 ; n=11)$ long; straight point $41(38-45$; $\mathrm{n}=1 \mathrm{1}$ ); elongate, evenly curved superficial root; base $67(61-79 ; n=11)$ long; inconspicuous deep root; angle shaft/point $52^{\circ}\left(46^{\circ}-60^{\circ} ; n=11\right)$. Superficial bar $32(29-38 ; n=11)$ long. $12(10-18$; $\mathrm{n}=11$ ) wide, with two lateral, anterior processes; processes of superficial bar $34(27-43 ; n=11)$ long; shield of superficial bar $33(29-38 ; n=10)$ long, $16(14-18 ; n=7)$ wide, distally spathulated, connected to bar by thin, dorsal bridge. Deep bar thin, flexible. Hooks long, with evenly curved shaft, 

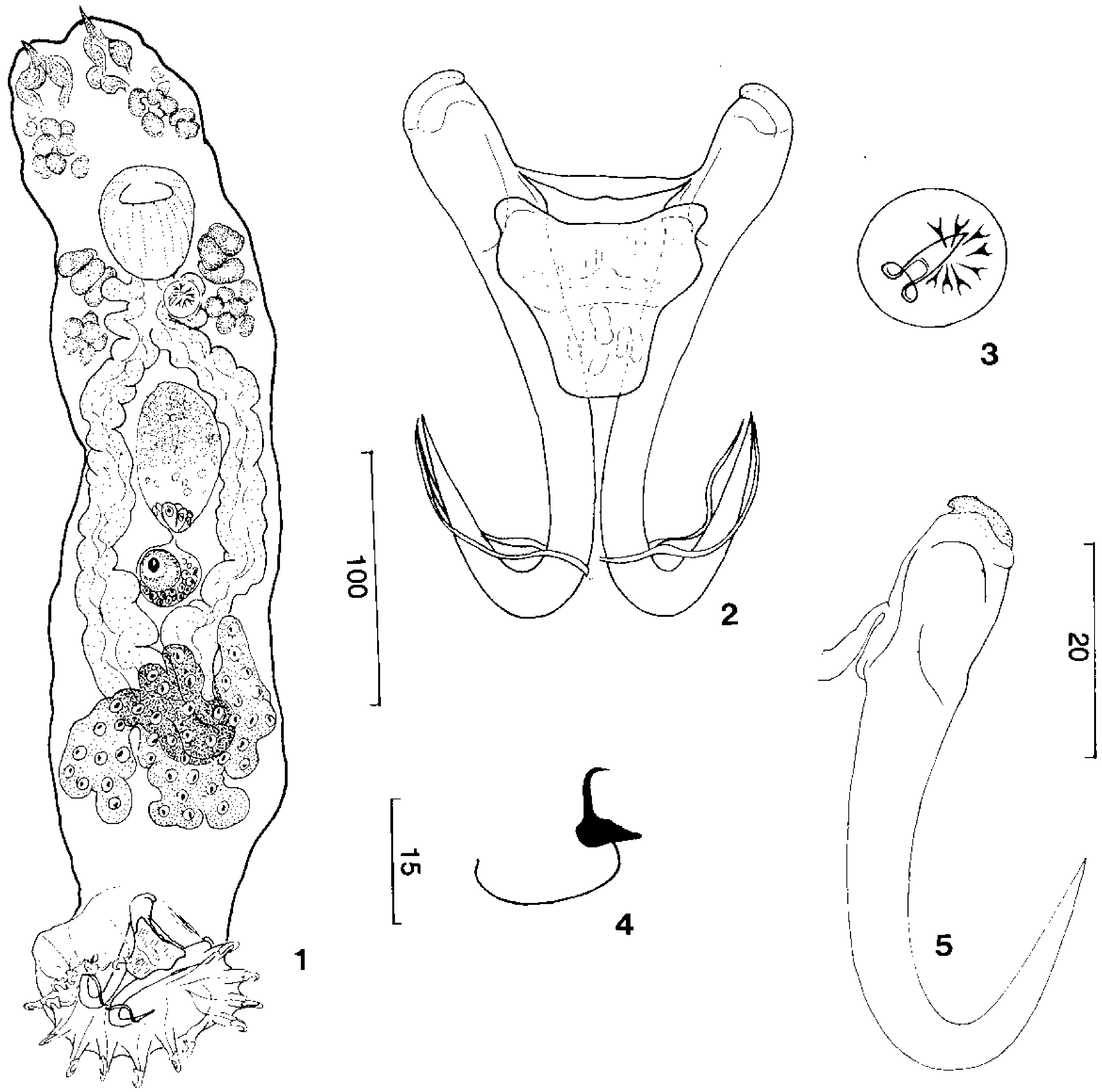

Gyrodactylus geophagensis n. sp. Fig. 1: holotype (ventral). Fig. 2: anchor-bar complex (ventral). Fig. 3: copulatory organ. Fig. 4: hook. Fig. 5: anchor. Figs 2, 3,5 are to the $20 \mu \mathrm{m}$ scale; other figures are to their respective scales.

point, depressed thumb, convex shelf, conspicuous heel; hooklet $6(5-8 ; n=18)$ long; FH loop $1 / 2$ shank length.

Remarks: Gyrodactylus trairae n. sp. resembles species included in the subgenus $G$. (Mesonephrotus) Malmberg, 1964 (see Malmberg 1970 ) and $G$. katherineri Malmberg, 1964 by the presence of long anterolateral processes on the superficial bar. Although, the presence of two arched rows of spinelets on the copulatory organ and the shape of the hooklets suggest proximity of the new species with those included in the subgenus Gyrodactylus (Gyrodactylus) (sensu Malmberg
1970). Independently of the subgeneric placement, however, the new species can be easily differentiated from all known Gyrodactylus by the morphology of the anchor and shield of the superficial bar. Additionally, the embryos of $G$. trairae, unlike those of other species in the genus, lie almost unfolded within the utenus. The specific name refers to the local name of the fish host ("traíra").

\section{ACKNOWLEDGMENTS}

To Dr Heraldo A Britsky (Museu de Zoologia, Universidade de São Paulo) for identification of the host species; Dr Delane C Kritsky (ldaho State University) and two anonymous referees for comments and suggestions. 

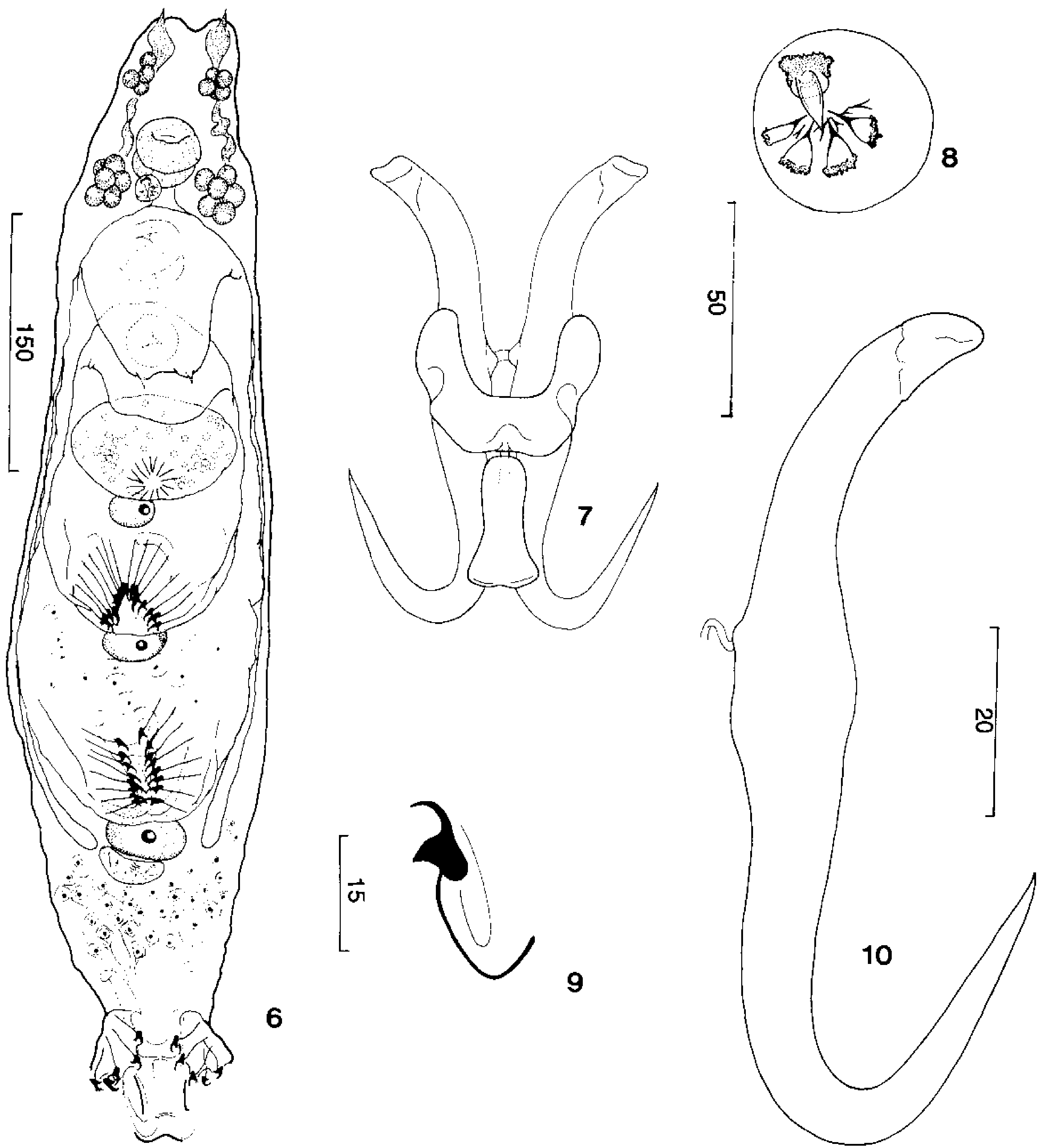

Gyrodactylus trairae n. sp. Fig. 6: holotype (ventral). Fig. 7: anchor -bar complex (ventral). Fig. 8: copulatory organ. Fig. 9: hook. Fig. 10: anchor. Figs 8,10 are to the $20 \mu \mathrm{m}$ scale; other figures are to their respective scales.

\section{REFERENCES}

An L. Jara CA, Cone DK 1991. Five species of Gyrodactylus Nordmann, 1832 (Monogenea) from freshwater fishes of Peru. Can J Zool 69: 109-202

Boeger WA, Kritsky DC, Belmont-Jégu E 1994. Neotropical Monogenoidea. 20. Two new species of oviparous Gyrodactylided (Polyonchoinea) from loricariid catfishes (Siluriformes) in Brazil and the phylogenetic status of Ooegyrodactylidae Harris, 1983. J helminth Soc Wash 61: 30-40.

Conroy G. Conroy DA 1985. Gyrodactylosis in silver mullet (Mugil curema Val.) from Venezuelan coastal waters, and a description of Gyrodactylus curemae n. sp. Riv ital Ittioparasit 20: 140-147.

Ferraz E, Shinn AP, Sommerville C 1994. Gyrodactylus gemini n. sp. (Monogenea: Gyrodactylidae), a parasite of Semaprochilodus taeniurus (Steindachner) from the Venezuelan Amazon. Syst Parasitol 29: $217-222$.

Harris PD 1983. The morphology and the life-cycle of the oviparous Oogyrodactylus farlowellae gen. et sp. nov. (Monogenea, Gyrodactylidea). Parasitology 87: 405-420.

Harris PD, Lyles AM 1992. Infections of Gyrodactylus 
bullatarudis and Gyrodactylus tumbulli on gupies (Poecilia reticulata) in Trinidad. J Parasitol 78: 913-914.

Jara CA 1986. Finding of Gyrodactylus sp. and Anacanthocotyle sp. (Monogenea, Gyrodactylidae) in fishes from the Moche River, Trujillo, Peru. Hydrobios 10: 8-13.

Jara CA, Cone DK 1989. Scleroductus yuncensi gen. et sp. n. (Monogenea) from Pimelodella yuncensis (Siluriformes, Pimelodidae) in Peru. Proc helm Soc Wash 56: 125-127.

Jara CA, An L, Cone DK 1991. Accessorius peruensis gen. et sp. $\mathrm{n}$. (Monogenea, Gyrodactylidea) from Lebiasina bimaculata (Characidac) in Peru. J helm Soc Wash 58: 164-166.

Kritsky DC, Boeger WA 1991. Neotropical Monogenea 16. New species of oviparous Gyrodactylidea with proposal of Nothogyrodactylus gen. $\pi$. (Ooegyrodactylidae). J helm Soc Wash 58: 7-15.

Kritsky DC, Bocger WA, Popazoglo F 1995. Neotropical Monogenoidea 22. Variation in Scleroductus species (Gyrodactylidae, Gyrodactylidea) from siluriform fishes of Southeastern Brazil. Jhelm Soc Wash 62: 53-56.
Kritsky DC, Fritts TH 1970. Monogenetic trematodes from Costa Rica with the proposal of Anacanthocotyle gen. $\mathrm{n}$. (Gyrodactylidea: Isancistrinae). Proc helm Soc Wash 37: 63-68.

Kritsky DC, Thatcher VE 1977. Phanerothecium gen. nov. and Fundulotrema gen. nov. two new genera of viviparous Monogenoidea (Gyrodactylidae), with a description of $P$. caballeroi $\mathrm{sp}$. nov, and a key to the subfamilies and genera of the family. Excerta Parasitologica en memória del doctor Eduardo Caballero y Caballero. Inst Biol Publ Esp 4: 5360.

Malmberg G 1970. The excretory systems and the marginal hooks as a basis of the systematics of Gyrodactylus (Trematoda: Monogenea). Ark Zool 23: 1-235.

Putz RE, Hoffman GL 1963. Two new Gyrodactylus (Irematoda: Monogenea) from cyprinid fishes with synopsis of those found on North American tishes. J Parasit 49: 559-566.

Szidat L 1973. Morphologie un Verhalten von Paragyodactylus superbus $\mathrm{n}$. g. n. sp. Iirregener eines Fischsterbens in Argentinien. Angew Parasitol 14: 1-10. 